\title{
PRENATAL THYMUS MORPHOGENESIS IN BOS TAURUS
}

\section{Lieshchova M. A., Gavrilin P. M.}

\section{INTRODUCTION}

The thymus is they of primary regulation of immune processes in the body and the primary organ of immunogenesis ${ }^{1}$. Here, under the influence of cellular components and humoral factors, synthesized by its epithelium, the undifferentiated precursor cells mature to immunocompetent T-lymphocytes, which subsequently populate the T-dependent zones of peripheral lymphoid organs $^{2}$. The anatomical structure of thymus has been extensively studied and described in humans and various taxonomic groups of the vertebrates ${ }^{3}$. In domestic animals (bulls, sheep, pigs, rabbits), the thymus is an impar organ that divides into a pair of cervical and impar thoracic particles. The cervical particle is represented by two cords that are located along the trachea, and the thoracic particle is located in the cranial section of the chest cavity ${ }^{4}$. Externally, thymus is covered by a capsule, and the membranes extending from it divide the organ into particles, but this division can be incomplete. In the mammalian parenchyma, the particles are divided into zones: cortical (peripheral) and medullary (central) ${ }^{5}$, however, there can be found the information of division of particles into three, four and five zones in the literature. The basis of each particle is the growing reticulo-epithelial cells, among which their different

${ }^{1}$ Воронин Е.С., Петров А.М., Серых М.М. Иммунология. Онтогенез иммунного ответа. Москва : Колос-Пресс, 2002. С. 332-338. $152 \mathrm{c}$.

Донцов В.И. Иммунобиология постнатального развития. Москва : Наука, 1990.

Pearse, G. Normal structure, function and histology of the thymus. Toxicologic Pathology. 2006. 34(5). P. 504-514. DOI :10.1080/01926230600865549.

2 Рабсон А., Ройт А., Делвз П. Основы медицинской иммунологии. Москва : Мир, 2006. 320 c.

Kay, H. E. M. The Thymus. Proceedings of the Royal Society of Medicine. 1970. 63(7). P. 715-717. DOI :10.1177/003591577006300727.

${ }_{3}^{3}$ Кемилева 3. Вилочковая железа. Москва : Медицина, 1984. 156 с.

4 Клименко О.М. Тимус сільськогосподарських тварин (атлас гістології i гістохімії тимуса сільськогосподарських тварин, птиці та риб). Рівне, 1999. 67 с.

5 Кузнецов А.В., Шевченко Б.П. Микроморфология тимуса свиней крупной белой породы в постнатальном периоде онтогенеза. Известия ОГАУ. 2012. № 35-1. С. 244-247. 
populations are distinguished ${ }^{6}$. Stem cells from the bone marrow colonize the subcapsular region of thymus particles, then initially transform into large lymphoblasts and give rise to a population of lymphocytes. The process of transformation of stem cells into mature T-cells is accompanied by the appearance or disappearance of "differential" markers on their surface under the action of thymic hormones ${ }^{7}$. During differentiation, T-lymphocytes move into the deeper areas of the cortical substance of the particles in contact with epithelial dendritic cells. The latter, through positive and negative selection, control the formation of autoreactive lymphocytes ${ }^{8}$. Lymphocytes tolerant of self-antigenes on the border with the medullary substance of particles, through the postcapillary veins with high endothelium, enter the bloodstream and then the T-dependent zones of peripheral lymphoid organs ${ }^{9}$.

The lymphocytes in medullary substance of the thymus are much smaller than in cortical substance. Some of these cells migrate here from cortical substance, and according to some authors ${ }^{10}$, a particle of the lymphocytes of medullary substance comes from the peripheral organs of immunogenesis to transmit certain information that is taken into account in the formation of new lymphocytes, that is, perform a regulatory function. Specific thymus formations are the Hassall's thymic corpuscles, which, under normal organogenesis, are characteristic only of medullary substance of the particles ${ }^{11}$. Information on the qualitative and quantitative characteristics of the tissue components of the mammalian parenchyma in terms of their functional specialization is scarce and relates mainly to the postnatal ontogenesis $^{12}$. The cellular composition of cortical and medullary substances

${ }^{6}$ Торбек В. Э., Юрина Н. А. Ультраструктура эпителиоцитов тимуса потомства при изменении гормонального фона в функциональной системе мать-плод. Вестник РУДН. Серия: Медицина. 2000. № 2 (48). С. 45-49.

${ }^{7}$ Kitagawa, Y., Sakaguchi, S. Development of Regulatory T Cells in the Thymus. Encyclopedia of Immunobiology. 2016. P. 268-274. DOI :10.1016/b978-0-12-3742797.04017-0

${ }^{8}$ Surh, C. D., Sprent, J. T-cell apoptosis detected in situ during positive and negative selection in the thymus. Nature. 1994. 372 (6501). P. 100-103. DOI :10.1038/372100a0

${ }_{9}$ Волошин Н.А., Григорьева Е.А. Структурные основы механизмов эмиграции лимфоцитов из тимуса. Актуальні питання морфологї: Фахове видання наукових праць III Національного конгресу анатомів, гістологів, ембріологів та топографоанатомів України. Тернопіль: “Укрмедкнига”. 2002. С. 60-61.

${ }^{10}$ Кемилева 3. Вилочковая железа. Москва : Медицина, 1984. 156 с.

11 Ярилин А.А., Гриневич В.Г., Пинчук В.Г. Структура тимуса и дифференцировка Т-лимфоцитов. Киев : Наукова думка, 1991. 248 с.

Клименко О.М. Розвиток і будова тимуса в представників різних таксономічних груп хребетних тварин: автореф. дис. на здобуття наук. ступеня д-ра. біол. наук : 14.03.09. Київський нац. ун-т ім. Т. Шевченка. Київ, 2003. 28 с. 
of the thymus particles has been extensively studied and described in humans and laboratory animals, both in the periods of prenatal and postnatal ontogenesis ${ }^{13}$ but in productive animals cytoarchitectonics of lymphoid tissue and its age dynamics during the prenatal period of development are practically absent.

\section{Recent research and publications analysis}

Thymus is known to be the only mature lymphoid organ in the prenatal period of ontogenesis, it is involved in the formation of the immune system of the fetus and maintain its optimal level of activity in adults.

In the study of cattle thymus in the prenatal period of ontogenesis, V.S. Hryhoriev ${ }^{14}$ revealed in the thickness of mesenchyma of 45-50 days of age prefetus islets of embryos of future thymus particles wrapped in several layers of mesenchymal cells. Their parenchyma is indifferent to cortical and medullary substances, and the cellular composition is homogeneous and represented by two types of large, similar in structure, cells. The first type of cells includes those of the epithelial reticulum, the second is the reticular cells of mesenchymal origin. These data coincide with the reports of other authors, who indicated that on the 50th day of age in the prefetus of cows there is a formation of particles, and on the 56-57th day of age cortex and medulla of the thymus particles appear ${ }^{15}$.

The next period in the development of thymus begins with the moment of the organ's settlement with lymphocytes. It is known that the source of humoral signals that cause migration into the organ of precursor cells from

Oliiar, A.V., Lieshchova, M.A. Structural and functional organization of central organs of hematopoiesis and immune protection of piglets during the early postnatal period of ontogenesis. Theoretical and Applied Veterinary Medicine. 2019. 7(1). P. 8-13. DOI : 10.32819/2019.71002

13 Волошин Н.А. Особенности морфогенеза тимуса крыс в антенатальном и постнатальном периодах в норме и после внутриутробного введения антигена : автореф. дис. на соискание уч. степени канд. мед. наук : 14.00.02. Крымский мед. ин-т. Симферополь, 1983. 21 с.

Кулида Л.В., Перетятко Л.П. Критические периоды морфогенеза тимуса на эмбриональном и фетальном этапах развития. Вестник РУДН. Серия: Медицина. 2009. № 7. C. 278-284.

${ }^{14}$ Григорьев В.С. Возрастные и половые особенности морфологии клеточного состава лимфатических узлов, тимуса крупного рогатого скота. Самара, 2000. $116 \mathrm{c}$.

15 Федик Ю.Я. Порівняльна морфологічна характеристика тимуса плодів і новонароджених телят. Вісник Білоцерківського держ. аграр. ун-ту. Біла Церква, 1998. Вип. 6, Ч. 1. С. 202-204. 
hematopoietic organs is epithelial cells ${ }^{16}$. However, structural mechanisms for the implementation of endocrine gland function have not been established yet $^{17}$. In the embryonic period, these signals are initially irregular, which implies the impulsive character of the population. Subsequently, this period becomes stable and is accompanied by an increase in the level of proliferative activity of cells.

Most authors believe that mammalian lymphocyte settlement occurs in the seventh-eighth week of embryonic development. A.H. Babaieva and Ye.O. Zotikov ${ }^{18}$ found that a small number of T-lymphocytes (up to 5\%) are detected in the embryonic thymus of a human at 7-8 weeks of development, and by the $11-12$ th week their number is already about $80-85 \%$. In the rat embryo, lymphoid colony-forming cells fill the epithelial germ on the 11th day $^{19}$, and on the 12th day in the mouse embryo ${ }^{20}$. Hemocytoblasts, large and medium lymphocytes and even a small number of small lymphocytes have been found in thymus particles of thymus since the 50th day of prenatal ontogenesis $^{21}$. Thymocytes differentiate from stem lymphoid cells, which are formed first in the wall of the yolk sac, then in the liver, and later in the bone marrow.

The next period of development of thymus is characterized by increase in weight of an organ, quantity of tissue structures and intensity of differentiation of cells. Within 3-5 months of intrauterine development in mammalian thymus, differentiation of stromal cells and appearance of T-lymphocyte species, i.e., killers, suppressors and helper cells, which can produce cytokinins, are observed. The formation of thymus is completed by the 6th month of age, when the body's epithelial-reticulocytes begin

16 Партенадзе А.Н., Студеникин В.М. Иммунофенотипические особенности становления иммунокомпетентных клеток в фетальном тимусе человека. Российский педиатрический журнал. 1998. № 4. С. 44-47.

${ }^{17}$ Торбек В.Э., Юрина Н.А. Ультраструктура эпителиоцитов тимуса потомства при изменении гормонального фона в функциональной системе мать-плод. Вестник РУДН. Серия: Медицина. 2000. № 2 (48). С. 45-49.

18 Бабаева А. Г., Зотиков Е.А. Иммунология процессов адаптивного роста, пролиферации и их нарушений. Москва : Наука, 1987. 208 с.

19 Волошин Н.А. Особенности морфогенеза тимуса крыс в антенатальном и постнатальном периодах в норме и после внутриутробного введения антигена : автореф. дис. на соискание уч. степени канд. мед. наук : 14.00.02. Крымский мед. ин-т. Симферополь, 1983. 21 с.

${ }^{20}$ Торбек В.Э., Юрина Н.А. Ультраструктура эпителиоцитов тимуса потомства при изменении гормонального фона в функциональной системе мать-плод. Вестник РУДН. Серия: Медицина. 2000. № 2 (48). С. 45-49.

${ }^{21}$ Григорьев В.С. Возрастные и половые особенности морфологии клеточного состава лимфатических узлов, тимуса крупного рогатого скота. Самара, 2000. 116 с. 
hormone secretion, and differentiated forms appear outside the thymus: T-killers, T-suppressors, T-helper cells ${ }^{22}$.

Subsequently, by the time of birth in the mammalian thymus there is an increase in the size of the particles, thickening of the capsule, an increase in the density of the arrangement of fibrous structures in it and interparticle connective tissue membranes ${ }^{23}$. In addition, there is a predominance of medullary substance over the cortical substance. Cytoarchitectonics of the cortical and medullary substances of the particles is characterized by a decrease in young forms of lymphocytes, mast cells and macrophages ${ }^{24}$.

After birth, all the animals and humans have an age physiological involution of thymus, which is accompanied by a decrease in the volume of the gland particles, the abrasion of the border between the cortical and medullary substances, the increase of the thickness of the interparticle connective tissue and the accumulation of lipids in it. Age involution captures primarily the cortical substance of particles to its full replacement, while maintaining the medullary area. However, admission of the precursors of T-lymphocytes to thymus and their maturation persist for $\operatorname{life}^{25}$. According to D. Metcalf ${ }^{26}$, the involutive processes in thymus begin as early as the prenatal period, when the peri- and intralobular connective tissues appear ${ }^{27}$.

Therefore, the study of the patterns of morphogenesis and structural and functional features of lymphoid organs in bos taurus, as a representative species of maturenate mammals, is currently an urgent problem. The lack of a single point of view on the morphological criteria for the formation of immunological reactivity does not allow for an adequate understanding of the pathogenesis of immunodeficiency conditions in newborns and significantly complicates the creation of effective methods of immunoprophylaxis and improvement of technologies for growing its resiliency and efficient practical use.

22 Ярилин А.А., Гриневич В.Г., Пинчук В.Г. Структура тимуса и дифференцировка Т-лимфоцитов. Киев : Наукова думка, 1991. 248 с.

${ }^{23}$ Babu, D. S., Padmavathi, M., Sailaja, V. A study on histogenesis of thymus gland in fetuses. International Journal of Anatomy and Research. 4(1). 2016. P. 2058-2061. DOI :10.16965/ijar.2016.137

24 Хлыстова 3.С. Развитие иммунной системы в онтогенезе человека. Архив патологии. 1991. Т. 53, № 11. С. 11-17.

${ }^{25}$ Palumbo, C. Embryology and anatomy of the thymus gland. Thymus Gland Pathology. 2008. P. 13-18. DOI :10.1007/978-88-470-0828-1_2

26 Metcalf, D. The Structure of the Thymus. The Thymus. 1966. P. 1-17. DOI : 10.1007/978-3-642-46044-9_1

${ }^{27}$ Haroun, H.S. Aging of thymus gland and immune system. MOJ Anatomy \& Physiology. 2018. 5(2). DOI :10.15406/mojap.2018.05.00186 


\section{Material and methods of research}

The study was conducted on the basis of the unit of morphological studies of the Scientific Research Centre of Biosafety and Environmental Control of Agro-Industrial Complex of the Dnipro State Agrarian and Economic University.

The thymus was extracted from feti of the bos taurus obtained from clinically healthy animals in the conditions of a meat processing enterprise in Dnipro (Ukraine) by anatomical preparation. A total of 48 organs from the feti of $2,3,4,5,6,7,8,9$ months of age (6 organs of each age) was examined. The age of the feti was determined by the weight and length of the body, as well as the development of integumentary structures according to A.P. Studentsov. The absolute mass of organs was determined, the relative mass of organs (by weight of the feti) was calculated. After fixation in $10 \%$ formalin solution, the thymus was cut in the segmental plane, perpendicular to the great vessels, and several plates from the cervical and thoracic particles were selected in places with maximum width. The organ fragments were poured into paraffin, histo sections of 5-7 $\mu \mathrm{m}$ thick, followed by Erlich's hematoxylin staining and eosin; azure-II - eosin, sudan III were made by conventional methods. Quantitative (morphometric) analysis of tissue components was performed according to the method of "point counting" using the Avtandilov's test system. In the cervical and thoracic particles of thymus, the percent area (PA) of the interparticle connective and lymphoid tissue (LT), as well as PA of the cortical and medullary substance of the particles, were determined. Microscopy of the

preparations was performed on Olimpus $\mathrm{CH}-20, \mathrm{CX}-41$ light microscopes (eyelens $10 \times$, lens $10 \times ; 40 \times ; 100 \times$ ). The results of the studies were statistically processed using one-way ANOVA test. In the tables, the data are presented as mean values $(\mathrm{X})$ and their standard deviations (SD).

\section{Results of the research}

The absolute weight of thymus of feti of 2 months of age is minimal and does not exceed $0.2 \mathrm{~g}$, which is $0.67 \%$ of the total weight of the fetus. The dynamics of the absolute mass of thymus is characterized by a gradual increase in it throughout the prenatal development period. Moreover, the highest growth is observed in feti of 3 and 5 months of age. The relative weight of thymus (to the weight of fetus) in feti during most of the foetal period of ontogeny slightly increases, its decrease is observed only in feti of 3 months of age (up to $0.28 \%$ ). The relative weight of thymus is maximal in feti of 9 months of age and minimum 3 months of age (table 1 ). 
Dynamics of absolute and total weights of thymus of feti

\begin{tabular}{|c|c|c|c|c|}
\hline \multirow{2}{*}{ Weight } & \multicolumn{4}{|c|}{ Age, months } \\
\hline & 2 & 3 & 4 & 5 \\
\hline Absolute, $\mathrm{g}$ & $0.20 \pm 0.070$ & $1.93 \pm 0.760$ & $2.86 \pm 0.600$ & $18.28 \pm 1.560 * * *$ \\
\hline Relative, \% & 0.67 & 0,28 & 0.30 & 0.52 \\
\hline $\begin{array}{l}\text { Weight of feti, } \\
\mathrm{kg}\end{array}$ & $0.03 \pm 0.005$ & $0.68 \pm 0.090$ & $0.96 \pm 0.130$ & $3.48 \pm 0.230$ \\
\hline \multirow{2}{*}{ Weight } & \multicolumn{4}{|c|}{ Age, months } \\
\hline & 6 & 7 & 8 & 9 \\
\hline Absolute, $g$ & $29.66 \pm 4.70$ & $64.50 \pm 8.250 * *$ & $141.3 \pm 4.900 * * *$ & $180.5 \pm 4.960 * * *$ \\
\hline Relative, \% & 0.57 & 0.60 & 0.66 & 0.72 \\
\hline $\begin{array}{l}\text { Weight of feti, } \\
\mathrm{kg}\end{array}$ & $5.19 \pm 0.430$ & $10.69 \pm 0.950$ & $21.50 \pm 3.370$ & $25.17 \pm 1.240$ \\
\hline
\end{tabular}

Note: $*-\mathrm{P} \leq 0.05, * *-\mathrm{P} \leq 0.01,{ }^{* * *}-\mathrm{P} \leq 0.001$, compared to previous age

Thymus of the bos taurus during the entire foetal period of ontogenesis has a characteristic particle structure with the presence of all the main functional zones of the lymphoid parenchyma and tissue structural components. The connectivetissue stroma is formed by a loose fibrous connective tissue that forms the capsule and the interparticular stroma of the organ. In the particles, the peripherally located cortical substance and the central medullary substances are clearly distinguished. Thymus corpuscles are found in medullary substance of thymus of the feti from 2 months of age (Fig. 1).
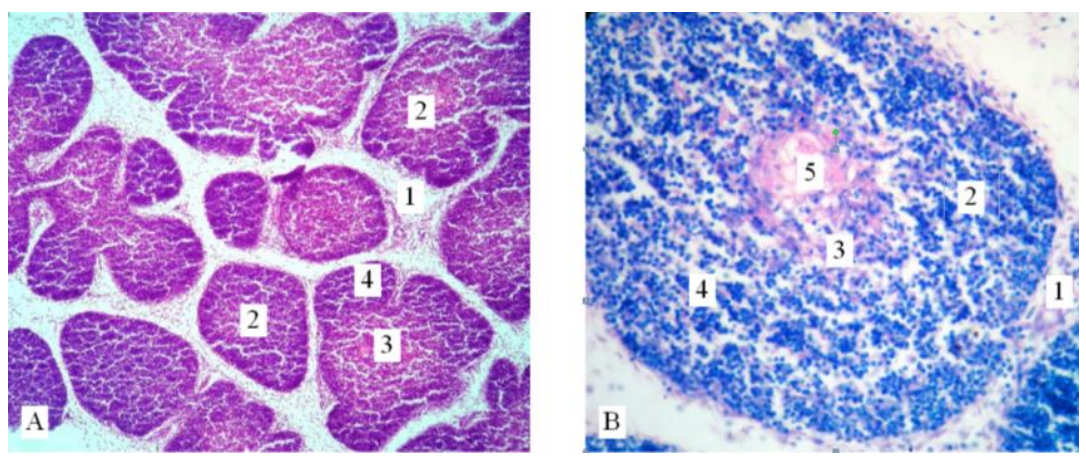

Fig. 1. Thymus of a bos taurus of 2 months of age: 1 - interparticle connective tissue, 2 - particles, 3 - medullary cord of the particle, 4 - cortical substance of the particle, 5 - thymic corpuscle. A - with hematoxylin and eosin, $\times 40 ; \mathrm{B}-$ with azure-II-eosin, $\times 100$ 
In thymus of feti of 2 months of age, the connective-tissue stroma occupies a considerable area, especially in the cervical particle of the organ $(31.8 \%)$ and slightly smaller in the thoracic particle (23.5\%). Its structure is characterized by significant development of the fibrous acontoid and the presence of numerous blood vessels. Accordingly, the percent area of lymphoid tissue in different thymus particles ranges from $68.2 \%$ in the cervical to $76.5 \%$ in the thoracic particles (Fig. 2, 3).

In thymus of feti of 2 months of age, the most formed particles with the presence of all the main structural components (cortical and medullary substance, thymic corpuscles) are located in the central zone of the organ particles, and the incomplete are on the periphery. The cortical and medullary substances in thymus particles are not of the similar areas, PA of the cortical substance reaches $53 \%$ in cortical particle and $49.8 \%$ in thoracic.

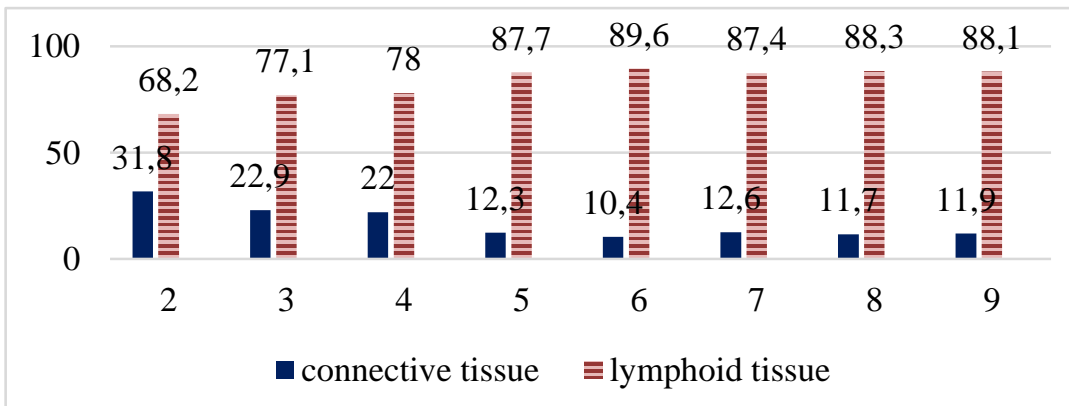

Fig. 2. Dynamics of the percent area of connective and lymphoid tissues in cervical thymus of feti, $\%$

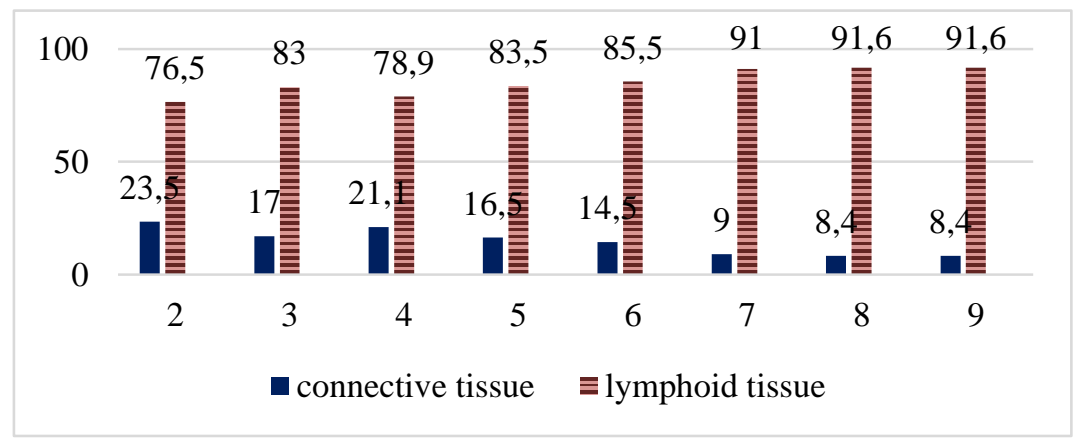

Fig. 3. Dynamics of the percent area of connective and lymphoid tissues in thoracic thymus of feti, $\%$ 
PA of medullary substance is almost 2-3 times smaller than that of the cortical. The ratio of medullary and cortical PA in particles in the cervical particle is 1:2.7, 1: 2.3 in thoracic (Table 2).

Table 2

\section{Dynamics of percent area of cortical and medullary substances} of thymus particles of feti, $\%$

\begin{tabular}{|c|c|c|c|c|c|c|c|c|}
\hline \multirow{2}{*}{ Indices } & \multicolumn{8}{|c|}{ Age, months } \\
\hline & 2 & 3 & 4 & 5 & 6 & 7 & 8 & 9 \\
\hline \multicolumn{9}{|c|}{ Cervical particle } \\
\hline $\begin{array}{l}\text { PA of cortical } \\
\text { substance, } \%\end{array}$ & $\begin{array}{c}49.8 \pm \\
4.25\end{array}$ & $\begin{array}{c}58.1 \pm \\
1.87\end{array}$ & $\begin{array}{c}46.1 \pm \\
0.80^{* * *}\end{array}$ & $\begin{array}{c}69.1 \pm \\
1.09 * * *\end{array}$ & $\begin{array}{c}71.0 \pm \\
0.88\end{array}$ & $\begin{array}{c}71.2 \pm \\
1.34\end{array}$ & $\begin{array}{c}56.7 \pm \\
0.91 * * *\end{array}$ & $\begin{array}{c}56.8 \pm \\
2.80\end{array}$ \\
\hline $\begin{array}{l}\text { PA of } \\
\text { medullary } \\
\text { substance, } \%\end{array}$ & $\begin{array}{c}18.4 \pm \\
0.22\end{array}$ & $\begin{array}{c}19.0 \pm \\
0.71\end{array}$ & $\begin{array}{c}31.9 \pm \\
0.90 * * *\end{array}$ & $\begin{array}{c}18.6 \pm \\
0.78 * * *\end{array}$ & $\begin{array}{c}18.6 \pm \\
0.84\end{array}$ & $\begin{array}{c}16.2 \pm \\
1.24\end{array}$ & $\begin{array}{c}31.6 \pm \\
0.95 * * *\end{array}$ & $\begin{array}{c}31.3 \pm \\
2.80\end{array}$ \\
\hline $\begin{array}{l}\text { Ratio of PA } \\
\text { of medullary } \\
\text { and cortical } \\
\text { substances }\end{array}$ & $1.0: 2.7$ & $1.0: 3.0$ & 1.0:1.4 & $1.0: 3.7$ & $1.0: 3.8$ & $1.0: 4.4$ & 1.0:1.8 & $1.0: 1.8$ \\
\hline \multicolumn{9}{|c|}{ Thoracic particle } \\
\hline $\begin{array}{l}\text { PA of cortical } \\
\text { substance, } \%\end{array}$ & $\begin{array}{c}53.3 \pm \\
1.45\end{array}$ & $\begin{array}{c}54.6 \pm \\
2.89\end{array}$ & $\begin{array}{c}53.7 \pm \\
2.13\end{array}$ & $\begin{array}{c}68.1 \pm \\
2.73 * * *\end{array}$ & $\begin{array}{c}66.2 \pm \\
0.73\end{array}$ & $\begin{array}{c}75.8 \pm \\
1.60^{* * * *}\end{array}$ & $\begin{array}{c}73.8 \pm \\
1.28 * * *\end{array}$ & $\begin{array}{c}74.6 \pm \\
1.62\end{array}$ \\
\hline $\begin{array}{l}\text { PA of } \\
\text { medullary } \\
\text { substance, \% }\end{array}$ & $\begin{array}{c}23.2 \pm \\
1.63\end{array}$ & $\begin{array}{c}28.3 \pm \\
2.02\end{array}$ & $\begin{array}{c}25.2 \pm \\
1.13\end{array}$ & $\begin{array}{c}15,4 \pm \\
0.88 * * *\end{array}$ & $\begin{array}{l}19.3 \pm \\
0.64^{* *}\end{array}$ & $\begin{array}{l}15.2 \pm \\
1.37^{*}\end{array}$ & $\begin{array}{c}17.7 \pm \\
1.15^{* * *}\end{array}$ & $\begin{array}{c}17.0 \pm \\
1.67\end{array}$ \\
\hline $\begin{array}{l}\text { Ratio of PA } \\
\text { of medullary } \\
\text { and cortical } \\
\text { substances }\end{array}$ & $1.0: 2.3$ & $1.0: 1.9$ & $1.0: 2.1$ & $1.0: 4.4$ & $1.0: 3.4$ & $1.0: 4.9$ & $1.0: 4.1$ & $1.0: 4.3$ \\
\hline
\end{tabular}

In medullary substances of the most developed thymus particles, thymic corpuscles are found, their average number and absolute dimensions are minimal in feti of 2 months of age.

By 3 months of age, the percent area of connective tissue decreases and, accordingly, lymphoid tissue increases. Maximum is in the cervical particle (8.9\%), slightly less is in the thoracic particle (6.5\%). Interparticle connective-tissue membranes become thinner and the number of formed particles increases. Thymus particles are preferably oval or oval-rectangular. The boundaries between cortical and medullary substances become clearer. The medullary PA increases in the thoracic particle (5.1\%) and slightly in the cervical particle $(0.6 \%)$. The ratio of PA of medullary and cortical substances increases in the cervical particle (up to 1:3) and decreases in the thoracic particle (up to 1:1.9). 
In cervical particle of thymus of feti of 4 months of age, the tendency to increase the area of lymphoid tissue against the background of decrease in connective tissue persists, while in the thoracic particle it decreases slightly and connective tissue increases (by 4.1\%) (see Fig. 2, 3). The vast majority of particles are fully formed, the boundaries between the cortical and medullary substances are clearly expressed (Fig. 4). PA of cortical substance decreases in the cervical particle (by 12.0\%) and slightly in the thoracic particle (by $0.9 \%$ ). PA of medullary substance significantly is increasing in the cervical particle $(6.2 \%)$, andslightly decreasing in the thoracic particle $(3.1 \%)$. There is a sharp decrease in the ratio of PA of medullary and cortical substances in cervical particles of thymus (up to 1:1.4) (Table 2).

By 5 months of age, there is an increase in the percent area of lymphoid tissue, the largest growth is established in the cervical particle (by 9.7\%), smaller in the thoracic particle (by 4.6\%). The percent area of the interparticle connective tissue decreases to $12.3 \%$ in the cervical particle, to $16.5 \%$ in the thoracic particle (see Fig. 2, 3). The structure of the tissue components of thymus in feti of 5 months of age changes significantly, which is primarily due to the significant development of LT in the cortical substance of the particles. It should be noted that the tendency of increasing the number of thymic corpuscles in medullary substance persists, but their diameter decreases (Fig. 5).
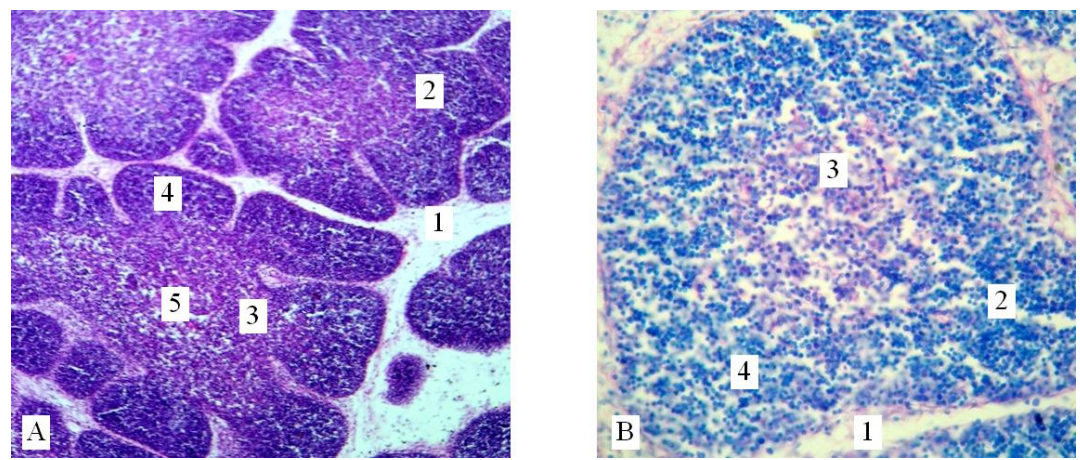

Fig. 4. Thymus of bos taurus of 4 months of age: 1 - interparticle connective tissue, 2 - particles, 3 - particles of medullary substances, 4 - particles of cortical substances, 5 - thymic corpuscle. A - with hematoxylin and eosin, $\times 100 ; B-$ with azure-II-eosin, $\times 400$

Thus, PA of cortical substance increases in the cervical particle (by 23\%), and in thoracic particle the increase does not exceed $14.4 \%$ (see Table 2). The decrease in PA of medullary substance of particles is 
accompanied by a change in medullary and cortical ratio, which in cervical particle was about 1:3.7, and in thoracic particle it was $1: 4.4$.

In thymus of feti of 6 months of age PA of LT of cervical particle significantly increases and reaches its maximum value for the whole period of prenatal development. Accordingly, PA of connective tissue decreases (see Fig. 2). In thoracic particle, an increase in PA of LT and decrease in connective tissue is observed within $2 \%$ (see Fig. 3). In thymus of feti of this age, moderate changes in PA of tissue components predominate. The intensity of the increase in PA of cortical substance of the particles slows down. In cervical particle, PA of cortical substance increases by only $1.9 \%$, and in thoracic substance it even decreases (by 1.9\%). A slight decrease in PA of medullary substance is observed in the cervical particle (up to $19.4 \%$ ), and in the thoracic substance it has significantly been increased (up to 19.3\%). In this regard, in cervical particles, the medullarycortical ratio does not change, but in thoracic particles, it decreases to 1: 3.4.
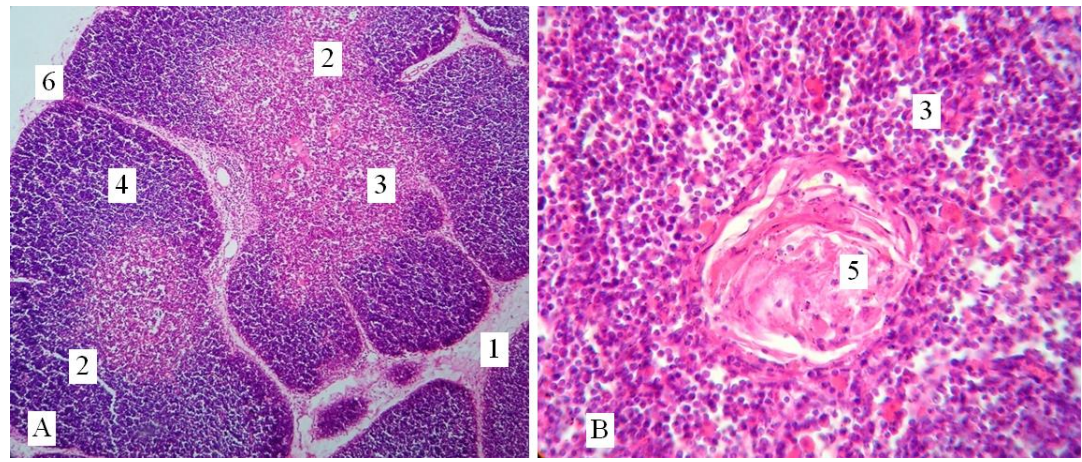

Fig. 5. Thymus of bos taurus of 5 months of age: 1 - interparticle connective tissue, 2 - particles, 3 - medullary substance of the particle, 4 - cortical substance of the particle, 5 - thymic corpuscle, 6 - capsule. $A-$ with hematoxylin and eosin, $\times 100 ; B-\times 400$

In thymus of feti of 7 months of age, a significant decrease in PA of LT (up to $87.4 \%$ ) and an increase in connective tissue (up to 12.6\%) is observed in the cervical particle, and in the thorax, on the contrary, PA of LT gradually increases (up to $91.0 \%$ ) and PA of connective tissue decreases (to $9.0 \%$ ). In the interparticle connective tissue, the amount and thickness of collagenous fibers increases and single fat cells appear, but the thickness of the connective-tissue membranes themselves is almost unchanged. In thymus particles, PA of cortical substances increases and reaches the 
maximum level, and PA of medullary substances decreases substantially and becomes minimal for the whole period of prenatal development. The ratio of PA of medullary and cortical substances in the thoracic and cervical particles of thymus is the highest of all (1: 4.9 and 1: 4.4, respectively).

Up to 8 months of age, increase in PA of lymphoid tissue and decrease in PA of connective tissue are noted in both the cervical and thoracic particles. In the cervical particle, PA of LT does not exceed $88.3 \%$, and in the chest particle it reaches maximum value for the entire period of prenatal development. PA of connective tissue slightly decreases in thoracic particle to $8.4 \%$ in cervical particle to $11.7 \%$ (see Fig. 2,3 ). The content of fat cells increases in the interparticle loose fibrous connective tissue of the organ. As a result, in both areas of cervical particle in the interparticle membranes, near the capsule, single fat cells and even their small clusters occur (Fig. 6).
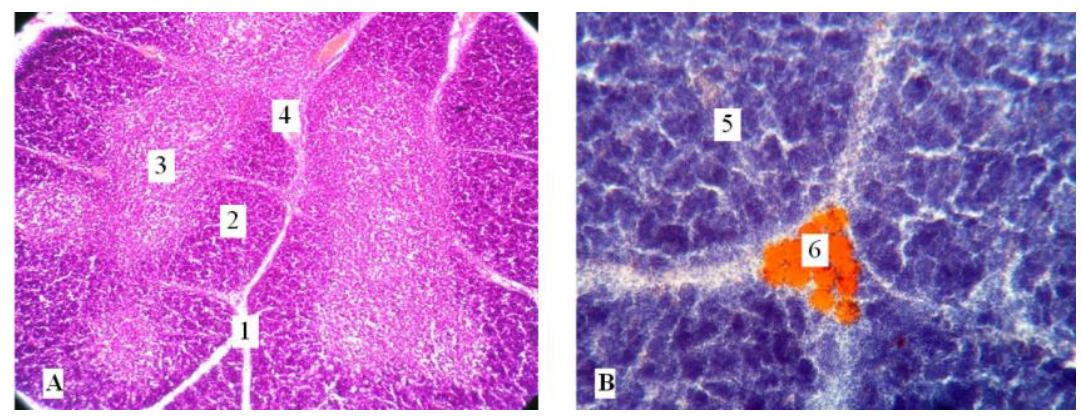

Fig. 6. Tissue specimen of thymus of a bos taurus of 8 months of age. With hematoxylin and eosin, $\times 100: 1$ - interparticle connective tissue; 2 - cortical and 3 - medullary substance of particles; 4 - blood vessels. B - with sudan-III and hematoxylin, $\times 100: 5$ - particles of thymus, 6 - uptake of adipocytes

Structural transformations of lymphoid tissue components are characterized by a sharp significant decrease in PA of cortical substance of cervical particles (by 14.5\%) and moderate thoracic (by 2\%) particles. PA of medullary substance in these particles significantly increases, in cervical particle it reaches $15.4 \%$, and in thoracic by $2.5 \%$. Medullary-cortical ratio in the cervical particles is $1: 1.8$, in thoracic particles it is $1: 4.1$ (see Table 2).

By the end of the prenatal period of ontogenesis in the cervical particle, PA of LT decreases (up to $88.1 \%$ ) and remains unchanged in the thoracic particle. PA of connective tissue at the end of the fetal period is maximal in cervical particle (11.9\%) and minimal in thoracic particle $(8.4 \%)$. 
The thymus of a bos taurus of 9 months of age is characterized by minor changes in the structure of the connective-tissue stroma and moderate lymphoid components. In the connective-tissue stroma of the thymus, the interparticle sections become more sophisticated, especially in the thoracic particle, and the content of fat cells increases slightly.

\section{Analysis of the results of experimental studies}

The patterns of morphogenesis of thymus of a bos taurus during prenatal ontogenesis are due to the general biological feature of the relative autonomy of intrauterine growth and development of mammals ${ }^{28}$, as well as to a number of personal specific features of the individual development of species of the herbivorous ungulates. The main feature is the high rate of prenatal formation of organs of the apparatus of motion and, accordingly, its basis, that is, the skeleton with bone marrow, organ of universal hematopoiesis and immune defense ${ }^{29}$, as well as the characteristic structure of the placenta and placental barrier in the ungulates, which provide a high level isolation of fetus from antigenic components circulating in blood of a mother ${ }^{30}$.

It is known that in postnatal ontogenesis changes in the quantitative and qualitative characteristics of mammalian thymus occur rhythmically. The uniqueness of structural and functional transformations of the thymus is manifested by the alternation of periods of marked increase in the volume of the parenchyma, with the subsequent development of the so-called physiological edema, the consequence of which is the intensive migration of lymphoid cells from thymus to the peripheral lymphoid organs. The result of eliminationof clones of T-lymphocytes from the thymus is a decrease in the lympho-epithelial ratio with a clear contour of the reticulo-epithelial base of the medullary marrow substance ${ }^{31}$. It is known that the death of lymphocytes in the thymus due to clonal selection, is most pronounced in the intervals between waves of emigration of thymic lymphoid cells. There is an emphasis on a decisive role of external factors that provoke the elimination

\footnotetext{
${ }^{28}$ Шмальгаузен И.И. Рост и дифференцировка. Киев : Наукова думка, 1984. Т. 2. $168 \mathrm{c}$.

29 Гаврилин П.Н. Особенности морфогенеза органов кроветворения у телят. Вет. медищина: Міжвід. тем. наук. зб. Харків : ІЕКВМ, 2000. Вип. 77. С. 65-70.

30 Биологические основы ветеринарной неонатологии : монография / Х.Б. Баймишев и др. Самара : РИЦ СГСХА, 2013. 452 с.

31 Gavrilin, P.N., Lieshchova, M.A., Gavrilina, O.G., Boldyreva, T.F. Prenatal morphogenesis of compartments of the parenchyma of the lymph nodes of domestic cattle (Bos taurus). Regulatory Mechanisms in Biosystems. 2018. 9(1). 95-104.
} 
of lymphocytes from thymus, which primarily relates to generic stress ${ }^{32}$, intense antigenic pressure in the period of postnatal adaptation ${ }^{33}$, the complex of abiotic factors (change of seasons, deterioration of weather

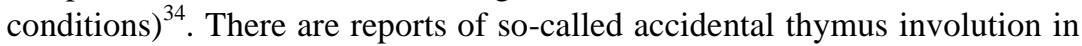
young productive animals under the influence of a set of anthropogenic factors in intensive livestock production, which is manifested by complete delimitation of the thymus with "exposure" of stroma and the development of a severe immunodeficiency status.

The data obtained indicate that the rhythmic manner of the growth and development of thymus in a domestic bull is characteristic of a foetal period of ontogenesis. The periodicity of structural and functional transformations in thymus manifests itself during the whole foetalperiod, and not only in the last months of prenatal life, as it is stated in the works of V.S. Hryhoriev ${ }^{35}$ and O.V. Blahodarova ${ }^{36}$.

It should be noted that the regularities of the periodicity of thymus morphogenesis in bos taurus have a number of significant differences from the postnatal transformations, which, in our opinion, is related to the relative autonomy of the prenatal development of the organ and indirect, through the body of a mother, the impact of environmental factors on the fetus ${ }^{37}$.

32 Волошин Н.А. Особенности морфогенеза тимуса крыс в антенатальном и постнатальном периодах в норме и после внутриутробного введения антигена: автореф. дис. на соискание уч. степени канд. мед. наук : 14.00.02. Крымский мед. ин-т. Симферополь, 1983. 21 с.

${ }^{33}$ Рожкова И.С., Теплый Д.Л., Фельдман Б.В., Тризно М.Н. Вилочковая железа в постнатальном онтогенезе белых крыс. Астраханский медицинский журнал. 2013. № 1. C. 211-214.

Юлдашева М.Т. Морфологическая и ультрамикроскопическая характеристика тимуса лабораторных групп животных препубертатного возраста. Биология $u$ интегративная медииина. 2017. № 4. С. 12-22.

${ }^{34}$ Мичурина С.В., Васендин Д.В., Ищенко И.Ю., Жданов А.П. Структурные изменения в тимусе после воздействия экспериментальной гипертермии. Вестник НГУ. Сер. Биология, клиническая медицина. 2010. Т. 8, вып. 1. С. 51-56.

Olearo, E., Oberto, M., Oggè, G., Botta, G., Pace, C., Gaglioti, P., Todros, T. Thymic volume in healthy, small for gestational age and growth restricted fetuses. Prenatal Diagnosis. 2012. 32(7). P. 662-667. DOI :10.1002/pd.3883.

${ }^{35}$ Григорьев В.С. Возрастные и половые особенности морфологии клеточного состава лимфатических узлов, тимуса крупного рогатого скота. Самара, 2000. 116 с.

${ }^{36}$ Благодарова О. В. Морфологія вилочкової залози людини в пренатальному періоді онтогенезу : автореф. дис. на здобуття наук ступеня канд. біол. наук : 14.03.09. Київський ун-т ім. Т.Шевченка. Київ, 1999. 19 с.

${ }^{37}$ Мороз Г.А. Строение тимуса интактных крыс-самцов линии Вистар разного возраста. СМБ. 2009. № 3-2. С. 98-102. 
It is noteworthy that, unlike the postnatal developmental period, a number of morphological parameters of the thymus in the fetus are relatively stable and tend to constantly increase, and the rhythm of their changes is manifested in the decrease or increase in the intensity of quantitative and qualitative characteristics.

Thus, according to our data, during the whole foetal period, and especially in the first half of it, feti of bos taurus increase the absolute and relative weight of thymus, the total number of LT and the proportion of small lymphocytes in the cortical and medullary substance of the particles of organ. The most labile structural parameters of thymus in bos taurus are the ratio of different zones of the lymphoid parenchyma (cortical and medullary substances), the degree of development and the number of thymic corpuscles.

In general, the dynamics of structural and functional transformations in thymus of fetus is determined by the alternation of periods of intensive growth and development of both "stable" and "labile" components of the lymphoid parenchyma, with periods of sharp changes in a number of structural characteristics of "labile" components, against the background of the decrease in the intensity of transformations relative to "stable" indicators.

According to our data, in thymus of animals in the foetal period of ontogenesis two peaks of increase of mass of an organ, the total volume of LT and PA of cortical substance of particles are noted. The first one, which in the cervical particle of the organ appears on the 3rd month of prenatal development, and the second one, more pronounced, which appears on the 7-8th month; it may indicate the two-stage nature of formation of T-cell zones of peripheral lymphoid organs in prenatal mammals ontogenesis.

In feti, we did not observe deep delimitation of the particle with the outline of the stroma of the organ, which would be accompanied by a sharp decrease in the indicators of absolute and relative weight of the organ ${ }^{38}$.

The established fact of clearly expressed variability of growth and development within individual particles of thymus in feti of bos taurus is not distinguished and is not discussed in the relevant scientific biological and medical literature, which may testify to the specificity of this structural phenomenon for the species maturenate animals, which have thymus with massive thoracic particle, as well as massive cervical particle that reaches the laryn $\mathrm{x}^{39}$. The aforementioned fact may also indicate a certain sequence of involvement of individual thymus particles in the formation of the T-cell

38 Гаврилин П.Н. Особенности морфогенеза органов кроветворения у телят. Вет. медицина: Міжвід. тем. наук. зб. Харків: IЕКВМ, 2000. Вип. 77. С. 65-70.

39 Клименко О.М. Тимус сільськогосподарських тварин (атлас гістології і гістохімії тимуса сільськогосподарських тварин, птиці та риб). Рівне, 1999. 67 с. 
level of immunity in the early period of ontogenesis. First of all, the potential of antigen-independent proliferation of the cervical thymus is realized in feti, and in the postnatal period of ontogeny it is realized in thoracicparticle, which is confirmed in a number of papers devoted to the study of the patterns of morphogenesis of lymphoid organs of productive animals inpostnatal period of development ${ }^{40}$.

It should be noted that with the biological phenomenon of maturenate animals, as a feature of the organism status in newborns, characteristic of a number of species of ungulates, including the bull domestic, is obviously associated with such a feature of thymus morphogenesis, as alternation of two successive phases of physiological hypertrophytic and delymphatization of the particles of thymus during the fertile period, in contrast to the singlephase of this process in most species of laboratory animals and humans ${ }^{41}$. This feature, in our view, may be due to the nature of prenatal morphogenesis in mammals that mature bone skeleton and, accordingly, the bone marrow, as sources of precursor cells ${ }^{42}$.

The appearance of individual fat cells and their accumulations in the interparticle connective tissue, established by us at feti of 7-9 months of age, is a sign of age-related involution of the organ and coincides with the development of the centers of the yellow bone marrow in the diaphysis of the tubular bones of feti of ungulates ${ }^{43}$.

In our opinion, the appearance of fat cells in thymus of feti of late stages of development, against the background of decrease in index of cortical substance of particles, more testifies to completion of prenatal "mission" of organ in formation of T-cell populations in peripheral organs of lymphocytopoiesis than its irreversible degenerative changes ${ }^{44}$.

According to some researchers, in the early postnatal ontogenesis in the period of active postnatal adaptation to a new spectrum of environmental factors, the wave-like principle of the dynamics of the total volume of LT in

40 Портнов В.А., Сеитов М.С. Изменения массы вилочковой железы коз оренбургской пуховой породы. Киров, 2005. 131 с.

Цыбикова Р.Н. Гистоструктура тимуса яков бурятского экотипа в постнатальном онтогенезе. Вестник КрасГАУ. 2007. № 4. С. 107-113.

${ }^{41}$ Babu, D.S., Padmavathi, M., Sailaja, V. A study on histogenesis of thymus gland in fetuses. International Journal of Anatomy and Research. 4(1). 2016. P. 2058-2061. DOI : $10.16965 /$ ijar.2016.137

${ }^{42}$ Haroun, H.S. Aging of thymus gland and immune system. MOJ Anatomy \& Physiology. 2018. 5(2). DOI :10.15406/mojap.2018.05.00186.

${ }^{43}$ Биологические основы ветеринарной неонатологии : монография / Х.Б. Баймишев и др. Самара : РИЦ СГСХА, 2013. 452 с.

44 Thymus involution. Encyclopedia of Immunotoxicology / H.W. Vohr (eds). Springer, Berlin, 2016. P. 891-891. 
organs and its redistribution within the particles between the cortical and medullary substances, is restored and reaches, in some cases, indicators characteristic of the late foetal period. The signs of age-related involution or degeneration of the organ in mammals are pronounced, according to A.A. Yarylina and others ${ }^{45}$, are marked after they reach puberty and physiological maturity. In some animals (reindeer and certain species of rodents), in the natural environment, the property of thymus of LT to recover after pre-degeneration with the onset of favorable climatic conditions, is practically preserved throughout life ${ }^{46}$.

\section{CONCLUSIONS}

Thymus in feti of bos tauruses of 2 months of age is characterized by the presence of all the main stromal and parenchymatous structural components (particles of lymphoid tissue, interparticle loose fibrous unformed connective tissue) with morphological features of functional activity (zonal structure of particles, heterogeneity of the population of lymphocytes, tymic corpuscles).

The dynamics of macro-microscopic and histological structural changes in both stromal and parenchymatous tissue components of thymus during the prenatal development period is characterized by a number of regularities. Structural transformations of connective-tissue stroma in thymus of feti are determined by the decrease in the total amount of connective tissue, the thinning of interparticle membranes, the thickening of collagenous fibers, the appearance of single fat cells and their accumulations in the interparticle connective tissue by the end of the foetal period.

Features of structural changes of lymphoid tissue within the thymus particles, characterized by its redistribution in favor of the cortical substance. In the cervical particle, the percent area of the cortical substance increases, reaching a maximum value within 6-7 months of age, with a subsequent decrease to 8 months of age and stabilization of this indicator up to 9 months of age. In the thoracic part, the percent area of the cortical substance increases from the beginning of the foetal period to 7 months of age, and remains at the same level until birth.

During the foetal period the percent area of medullary substance in cervical particle increases in almost 2 times, and in thoracic it decreases in

45 Ярилин А.А., Гриневич В.Г., Пинчук В.Г. Структура тимуса и дифференцировка Т-лимфоцитов. Київ : Наукова думка, 1991. 248 с.

46 Клименко О.М. Розвиток і будова тимуса в представників різних таксономічних груп хребетних тварин : автореф. дис. на здобуття наук. ступеня д-ра. біол. наук : 14.03.09. Київський нац. ун-т ім. Т. Шевченка. Київ, 2003. 28 с. 
1.4 times. The greatest development of the cortical substance of the particles, with a corresponding medullary-cortical ratio in the cervical and thoracic particles, is in feti of 7 months of age, the lowest is in those of 4 months of age in cervical particles, and infetiof 3 months of age in thoracic particles.

Structural and functional transformations of thymus of bos taurus in the foetal period of ontogenesis have a pronounced rhythmic manner with a consistent alternation of the phases of intensive increase of all basic morphometric parameters (the 1st and 3rd phases) with the phases of pronounced organ delymphatization (the $2 \mathrm{nd}$ and 4 th phases). The duration of the 1 st phase is from the 2 nd to the 3 rd month of the foetal period; the $2^{\text {nd }}$ phase is from the 3 rd to the 4 th months; the 3 rd phase is from the 4th to the 7 th months; the 5 th phases is from 7 th to 9 th months.

\section{SUMMARY}

The main condition for the efficient use of productive animals is to ensure an adequate level of their viability, which is impossible without taking into account the morphological aspects of their growth and development. The morphofunctional status of the immune protection organs, in particular the thymus, largely determines the state of natural resistance, nonspecific and immunological reactivity of the organism. There are regularities of morphogenesis and structural and functional specialization of parenchyma of thymus in feti of bos taurus, representative of maturenate productive mammals with the desmochorial type of placenta at the organ and tissue levels of the structural organization determined in the work with the help of morphological methods. As a result of complex analysis, it has been established that the structural and functional transformations of its tissue components have a rhythmic manner with sequential alternation of phases of functional activity, which has been manifested by hyperplasia of parenchyma and phases of hypofunction with delymphatization of parenchyma of the organ. It has also been found that age-related structural transformations of thymus within its individual particles occur asynchronously. At the beginning of the foetal period, the quantitative ratios of the tissue components of thymus are characterized by a high content of interparticle connective tissue, and in the cervical particle its percent area is much larger than in the thoracic part. During the development there is a steady tendency to increase the percent area of lymphoid tissue. The highest indicator of the percent area of lymphoid tissue of the cervical particle has been set at the age of 6 months, and in the thoracic particle it is only at the moment of birth. Structural transformations of connective-tissue stroma in thymus of feti are determined by the decrease in the total amount of connective tissue, the thinning of interparticle membranes, the thickening of collagenous fibers, the appearance of single fat cells and their 
accumulations in the interparticle connective tissue by the end of the foetal period. Structural changes of lymphoid tissue within the thymus particles are characterized by its redistribution in favor of cortical substance. In the cervical part, the percent area of the cortical substance increases, reaching a maximum value within 6-7 months of age, with a subsequent decrease to 8 months of age and stabilization of this indicator up to 9 months of age. In the thoracic part, the percent area of the cortical substance increases from the beginning of the foetal period to 7 months of age, and remains at the same level until birth. The greatest development of the cortical substance of the particles, with a corresponding medullary-cortical ratio in the impar area of the cervical particle, is in feti of 7 months of age, the smallest is in feti of 4 months of age. In cortical part, the greatest development is also in feti of 7 months of age, and the smallest is in feti of 3 months of age. The average number of thymic corpuscles in medullary substance of the thymus particles gradually increases in all parts of thymus. Thus, structural and functional transformations of thymus of bos taurus during the prenatal ontogenesis period have characteristic features for each particle and pronounced rhythmic manner with a consistent alternation of the phases of intensive increase of all major morphometric parameters from the 2nd to 3rd month of age and the 4th to 7th month of age with phases of expressed organ delymphatization from the 3rd to 4th month of age and 7 th to 9 th month of age.

\section{REFERENCES}

1. Бабаева А.Г., Зотиков Е.А. Иммунология процессов адаптивного роста, пролиферации и их нарушений. Москва : Наука, 1987. 208 с.

2. Биологические основы ветеринарной неонатологии : монография / Х.Б. Баймишев и др. Самара : РИЦ СГСХА, 2013. 452 с.

3. Благодарова О.В. Морфологія вилочкової залози людини в пренатальному періоді онтогенезу : автореф. дис. на здобуття наук ступеня канд. біол. наук : 14.03.09. Київський ун-т ім. Т.Шевченка. Київ, 1999. 19 с.

4. Волошин Н.А., Григорьева Е.А. Структурные основы механизмов эмиграции лимфоцитов из тимуса. Актуальні питання морфології: Фахове видання наукових праџь III Національного конгресу анатомів, гістологів, ембріологів та топографоанатомів України. Тернопіль : "Укрмедкнига", 2002. С. 60-61.

5. Волошин Н.А. Особенности морфогенеза тимуса крыс в антенатальном и постнатальном периодах в норме и после внутриутробного введения антигена : автореф. дис. на соискание уч. степени канд. мед. наук : 14.00.02. Крымский мед. ин-т. Симферополь, 1983. 21 с.

6. Воронин Е.С., Петров А.М., Серых М.М. Иммунология. Онтогенез иммунного ответа. Москва : Колос-Пресс, 2002. С. 332-338. 
7. Григорьев В.С. Возрастные и половые особенности морфологии клеточного состава лимфатических узлов, тимуса крупного рогатого скота. Самара, 2000. 116 с.

8. Гаврилин П.Н. Особенности морфогенеза органов кроветворения у телят. Ветеринарна медииина: міжвідомчий тематичний науковий збірник. Харків : ІЕКВМ, 2000. Вип. 77. С. 65-70.

9. Донцов В.И. Иммунобиология постнатального развития. Москва : Наука, 1990. 152 с.

10.Кемилева 3. Вилочковая железа. Москва : Медицина, 1984. 156 с.

11.Клименко О.М. Тимус сільськогосподарських тварин (атлас гістології і гістохімії тимуса сільськогосподарських тварин, птиці та риб). Рівне, 1999. 67 с.

12.Клименко О.М. Розвиток і будова тимуса в представників різних таксономічних груп хребетних тварин : автореф. дис. на здобуття наук. ступеня д-ра. біол. наук : 14.03.09. Київський нац. ун-т ім. Т. Шевченка. Київ, 2003. 28 с.

13.Кузнецов А.В., Шевченко Б.П. Микроморфология тимуса свиней крупной белой породы в постнатальном периоде онтогенеза. Известия ОГАУ. 2012. № 35-1. С. 244-247.

14.Кулида Л.В., Перетятко Л.П. Критические периоды морфогенеза тимуса на эмбриональном и фетальном этапах развития. Вестник РУДН. Серия: Медицина. 2009. № 7. С. 278-284.

15.Мичурина С.В., Васендин Д.В., Ищенко И.Ю., Жданов А.П. Структурные изменения в тимусе после воздействия экспериментальной гипертермии. Вестник НГУ. Сер. Биология, клиническая медииина. 2010. Т. 8, вып. 1. С. 51-56.

16.Мороз Г.А. Строение тимуса интактных крыс-самцов линии Вистар разного возраста. СМБ. 2009. № 3-2. С. 98-102.

17.Партенадзе А.Н., Студеникин В.М. Иммунофенотипические особенности становления иммунокомпетентных клеток в фетальном тимусе человека. Российский педиатрический журнал. 1998. № 4. С.44-47.

18. Портнов В.А., Сеитов М.С. Изменения массы вилочковой железы коз оренбургской пуховой породы. Киров, 2005. 131 с.

19.Рабсон А., Ройт А., Делвз П. Основы медицинской иммунологии. Москва : Мир, 2006. 320 с.

20.Рожкова И.С., Теплый Д.Л., Фельдман Б.В., Тризно М.Н. Вилочковая железа в постнатальном онтогенезе белых крыс. Астраханский медииинский журнал. 2013. № 1. С. 211-214.

21.Торбек В.Э., Юрина Н.А. Ультраструктура эпителиоцитов тимуса потомства при изменении гормонального фона в функциональной 
системе мать-плод. Вестник РУДН. Серия: Медицина. 2000. № 2 (48). C. 45-49.

22. Федик Ю.Я. Порівняльна морфологічна характеристика тимуса плодів і новонароджених телят. Вісник Білочерківського державного аграрного університету. Біла Церква, 1998. Вип. 6, Ч.1. С. 202-204.

23. Хлыстова 3.С. Развитие иммунной системы в онтогенезе человека. Архив патологии. 1991. Т. 53, № 11. С. 11-17.

24.Шмальгаузен И.И. Рост и дифференцировка. Киев : Наукова думка, 1984. Т. 2. 168 с.

25.Ярилин А.А., Гриневич В.Г., Пинчук В.Г. Структура тимуса и дифференцировка Т-лимфоцитов. Київ : Наукова думка, 1991. 248 с.

26.Цыбикова Р.Н. Гистоструктура тимуса яков бурятского экотипа в постнатальном онтогенезе. Вестник КрасГАУ. 2007. № 4. С. 107-113.

27.Юлдашева М.Т. Морфологическая и ультрамикроскопическая характеристика тимуса лабораторных групп животных препубертатного возраста. Биология и интегративная медицина. 2017. № 4. C. $12-22$.

28.Babu, D.S., Padmavathi, M., Sailaja, V. A study on histogenesis of thymus gland in fetuses. International Journal of Anatomy and Research. 4(1). 2016. P. 2058-2061. doi:10.16965/ijar.2016.137

29.Gavrilin, P.N., Lieshchova, M.A., Gavrilina, O.G., Boldyreva, T.F. Prenatal morphogenesis of compartments of the parenchyma of the lymph nodes of domestic cattle (Bos taurus). Regulatory Mechanisms in Biosystems. 2018. 9(1). 95-104. doi:10.15421/021814

30.Haroun, H.S. Aging of thymus gland and immune system. MOJ Anatomy \& Physiology. 2018. 5(2). doi:10.15406/mojap.2018.05.00186

31.Kay, H.E. M. The Thymus. Proceedings of the Royal Society of Medicine. 1970.63(7). P. 715-717. doi:10.1177/003591577006300727.

32. Kitagawa, Y., Sakaguchi, S. Development of Regulatory T Cells in the Thymus. Encyclopedia of Immunobiology. 2016. P. 268-274. doi: 10.1016/b978-0-12-374279-7.04017-0.

33. Metcalf, D. The Structure of the Thymus. The Thymus. 1966. P. 1-17. doi:10.1007/978-3-642-46044-9_1.

34.Olearo, E., Oberto, M., Oggè, G., Botta, G., Pace, C., Gaglioti, P., Todros, T. Thymic volume in healthy, small for gestational age and growth restricted fetuses. Prenatal Diagnosis. 2012. 32(7). P. 662-667. doi:10.1002/pd.3883.

35. Oliiar, A.V., Lieshchova, M.A. Structural and functional organization of central organs of hematopoiesis and immune protection of piglets during the early postnatal period of ontogenesis. Theoretical and Applied Veterinary Medicine. 2019. 7(1). P. 8-13. doi:10.32819/2019.71002 
36.Palumbo, C. Embryology and anatomy of the thymus gland. Thymus Gland Pathology. 2008. P. 13-18. doi:10.1007/978-88-470-0828-1_2

37.Pearse, G. Normal structure, function and histology of the thymus. Toxicologic Pathology. 2006. 34(5). P. 504-514. doi:10.1080/ 01926230600865549

38. Surh, C. D., Sprent, J. T-cell apoptosis detected in situ during positive and negative selection in the thymus. Nature. 1994. 372(6501). P. 100-103. doi: $10.1038 / 372100 \mathrm{a} 0$

39. Thymus involution. Encyclopedia of Immunotoxicology / H.W. Vohr (eds). Springer, Berlin, 2016. P. 891-891. doi:10.1007/978-3-642-545962_100541

Information about authors:

Lieshchova M. A.,

Candidate of Veterinary Sciences, Associate Professor of Department of Normal and Pathological Anatomy of Agricultural Animals

Dnipro State Agrarian and Economic University 25, Serhii Efremov str., Dnipro, 49000, Ukraine

Gavrilin P. M., Doctor of Veterinary Sciences, Professor of Department of Normal and Pathological Anatomy of Agricultural Animals Dnipro State Agrarian and Economic University 25, Serhii Efremov str., Dnipro, 49000, Ukraine 